\title{
Approaches and reflexions on advance healthcare directives in Brazil
}

\author{
Abordagens e reflexões sobre diretivas antecipadas da vontade no Brasil \\ Enfoques y reflexiones sobre las directivas anticipadas en Brasil
}

\section{Luiz Carlos Ufei Hassegawa' \\ ORCID: 0000-0003-2590-6629 \\ Marcelo Custódio Rubira" ORCID: 0000-0002-3550-9718}

Solange Mendes Vieira' ORCID: 0000-0002-9340-3495

Ana Paula de Angelis Rubira" ORCID: 0000-0001-8621-8227

Tony Hiroshi Katsuragawa"' ORCID: 0000-0001-7900-5637

José Hiran Gallo'v ORCID: 0000-0002-1848-7270

Rui Manuel Lopes Nunes ${ }^{v}$ ORCID: 0000-0002-1377-9899

' Secretaria Saúde do Estado de Rondônia, Hospital de Base Ary Pinheiro. Porto Velho-RO, Brasil. "Instituto Luterano Ensino Superior. Porto Velho-RO, Brasil.

I' Centro de Pesquisa em Medicina Tropical. Porto Velho-RO, Brasil.

" Conselho Federal de Medicina. Brasília-DF, Brasil.

${ }^{v}$ Universidade do Porto, Faculdade de Medicina. Porto, Portugal.

How to cite this article: Hassegawa LCU, Rubira MC, Vieira SM, Rubira APA, Katsuragawa TH, Gallo JH, et. al. Approaches and reflexions on advance healthcare directives in Brazil. Rev Bras Enferm [Internet]. 2019;72(1):256-64. DOI: http://dx.doi.org/10.1590/0034-7167-2018-0347

Corresponding Author: Luís Carlos Ufei Hassegawa E-mail: hassega@gmail.com

\section{ABSTRACT}

Objective: to explain the approaches and discussions about the Advance Healthcare Directives spread among health professionals, lawyers and society. Method: bibliographic search in the databases SciELO, LILACS, BDENF, in Portuguese, carried out from December 2017 to January 2018. Results: 22 articles were considered for analysis with interviews and testimonies of physicians, intensivists and geriatricians, nurses, technicians and Nursing auxiliaries, Medical students, lawyers and Law students. Conclusion: there is a small number of papers on the Advance Healthcare Directives in Brazil, and a wide range of approaches that have not yet been clarified. The theme is not widely spread and little clarified in its essence. Descriptors: Living Will; Early Directives; Bioethics, Personal Autonomy, Right to Die.

\section{RESUMO}

Objetivo: explicitar as abordagens e discussões sobre as Diretivas Antecipadas da Vontade difundidas entre os profissionais de saúde, advogados e a sociedade. Método: pesquisa bibliográfica nas bases de dados SciELO, LILACS, BDENF, em Língua Portuguesa, realizada no período de dezembro de 2017 a janeiro de 2018. Resultados: foram considerados 22 artigos para análise com entrevistas e depoimentos de médicos, intensivistas e geriatras, enfermeiros, técnicos e auxiliares de Enfermagem, estudantes de Medicina, de Direito e advogados. Conclusão: há um pequeno número de trabalhos sobre as Diretivas Antecipadas da Vontade no Brasil, e uma ampla gama de abordagens ainda pouco elucidadas. O tema ainda é pouco difundido e pouco esclarecido em sua essência.

Descritores: Testamentos quanto à Vida; Diretivas Antecipadas; Bioética, Autonomia Pessoal, Direito a Morrer.

\section{RESUMEN}

Objetivo: explicitar los enfoques y discusiones sobre las Directivas Anticipadas difundidas entre los profesionales de la salud, los abogados y la sociedad. Método: investigación bibliográfica realizada en las bases de datos SciELO, LILACS, BDENF, en portugués, del diciembre 2017 hasta enero 2018. Resultados: se consideraron 22 artículos para el análisis con entrevistas y testimonios médicos, intensivistas y geriatras, enfermeros, técnicos y auxiliares de Enfermería, estudiantes de Medicina, de Derecho y abogados. Conclusión: hay un pequeño número de trabajos sobre las Directivas Anticipadas en Brasil, y una amplia gama de enfoques poco elucidados. El tema sigue siendo poco difundido y poco esclarecido en su esencia.

Descriptores: Testamentos sobre la Vida; Directivas Anticipadas; Bioética, Autonomía Personal, Derecho a Morir. 


\section{INTRODUCTION}

Individual and social values have changed throughout times and situations, and thus have also changed moral standards. What was considered absurd came to be normality. This happened with the death of the human body, which went from something untouchable to simple material to be used for the survival of another ${ }^{(1)}$.

With the evolution of civilized society there was a judicialization of death. What was characterized by any individual in society as the cessation of life, came to have eminently scientific and legal connotations; and tests or procedures were necessary for the characterization of death. Today, with cutting-edge technology and the specialization of Medical Science, dying has become slow and often painful(2).

Then some new concepts arise during the disease process. The patient who is beyond therapeutic possibility and yet has his/her body invaded will be the victim of dysthanasia, that is, the methods used cause suffering without any further clinical improvement. Orthotanasia refers to the acts and procedures used in terminal patients so that death occurs with the maximum possible comfort ${ }^{(3)}$.

With the emergence of Bioethics, a science that has emerged to unite the advances of biotechnology with the study of ethics and its implications, the act of dying takes on another dimension. Man begins to have control over life and, consequently, death: a hopeful power, but extremely dangerous ${ }^{(1)}$.

In the São Paulo State there is a law that deals with the rights of terminal patients of the health system, allowing them to refuse medical treatment. Law 10.245/1999 states that it is the patient's right to refuse painful or extraordinary treatments to try to prolong life ${ }^{(4)}$.

Resolution No. 41/1.995 of the National Council for the Rights of the Child and Adolescent (CONANDA), legally bound to the Ministry of Justice, in a text prepared by the Brazilian Society of Pediatrics, ensures the young or infant patient the right to a dignified death together to their families, when all therapeutic resources available have been depleted ${ }^{(5)}$.

More recently, in 2012, the Federal Council of Medicine (CFM), through CFM Resolution 1.995/1.995, legitimizes the medical position on patients' advance directives. In addition to its timeliness and innovation in the face of new technical and scientific challenges, it guarantees, with regard to decisions on care and treatment, the consideration of the prior will and expressly declared by the patient, provided that in accordance with the precepts determined by the Code of Medical Ethics; this will must prevail over any other non-medical opinion, including the will of family members ${ }^{(6)}$.

The Advance Healthcare Directives (AHD) are understood as the set of will previously expressed by the patient about care and treatment that he or she will to receive when unable to freely and autonomously express his/her will. AHD recognize the patient's right to refuse futile medical care, also known as extraordinary treatment, that is, treatments that aim only to prolong their biological life without guaranteeing their quality ${ }^{(7)}$.

In Brazil, there is still no specific legislation for AHD, and since CFM Resolution 1.995/2012, discussions have taken place informally and discreetly among groups of professionals. Scientific studies bring up this discussion, which for many there remains some confusion.

The present study questions whether there is an expressive approach to the Advance Healthcare Directives in the literature.

\section{OBJECTIVE}

To know the diverse lines of approaches and reflections on the Advance Healthcare Directives contained in articles published in Brazil.

\section{METHOD}

\section{Type of study}

An integrative review of the literature was conducted, making it possible to collect, analyze, synthesize and present the approach of multiple studies published on the subject in a systematic and orderly manner, contributing to the knowledge of its current approaches.

\section{Methodological procedures}

The subject, and the inclusion and exclusion criteria were defined; the articles were selected; the interpretation of results and presentation of the review were carried out ${ }^{(8)}$. The formulation of the problem included the following guiding question: approaches and reflections on AHD contained in articles published in Brazil.

\section{Data sources}

research was carried out in the world wide web, in the Virtual Health Library (VHL) databases: Scientific Electronic Library Online (SciELO), Latin American and Caribbean Literature in Health Sciences (LILACS) and Nursing Database (BDENF).

Data collection occurred from October 2017 to January 2018. The descriptors "medical directives" (MD), "advance directives" (AD) and "living will" (LW), referred to in the Descriptors in Health Sciences (DeCS) were used to select articles produced in Brazil and their different approaches, in addition to the association of key words. After the search for scientific productions, an analysis of the articles was carried out to verify their approximation with the proposed objective.

\section{Sample; inclusion and exclusion criteria}

For refinement, the following inclusion criteria were defined: scientific articles that explained the methodological procedures adopted, written in Portuguese, without restriction regarding the year of publication and related to the descriptors.

They were then subjected to careful reading of the title and abstract, verifying their suitability to the theme.

\section{Data analysis}

In the search for the national articles in the databases described, considering the mentioned descriptors, 72 articles were found. With the descriptor Advance Healthcare Directive 26 articles were found in the VHL, in the databases SciELO, LILACS, BDENF, in Portuguese, from 2011 to 2017. 


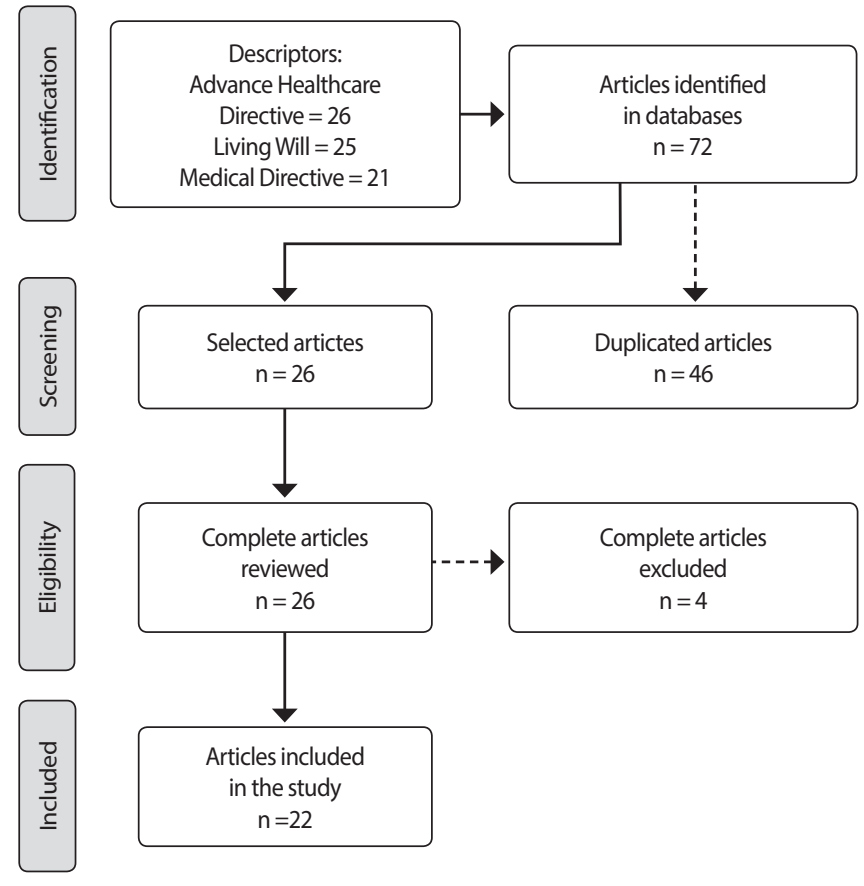

Figure 1 - Flow chart of the selection of articles
With the descriptor "MD" 25 articles were found; with "LW", 21 articles in the databases SciELO, LILACS and BDENF, from 2011 to 2015. A total of 46 articles was excluded by repetition. In addition to these, a thesis, a monograph and a letter to the editor. Regarding the association of keywords, five articles were found. They were then subjected to careful reading of the title and abstract, verifying their suitability to the theme (Figure 1).

\section{Data organization}

For the demonstration of the approaches to the topic, a data collection instrument was created (Chart 1), containing: year of publication, title of article, main referenced approaches, results and conclusions. Finally, the articles were analyzed in full, and the results were produced in a descriptive way.

\section{RESULTS}

At the end, 22 papers were considered for analysis. Studies with interviews and testimonies of physicians, intensivists and geriatricians, nurses, Nursing technicians and assistants, Medical students, lawyers and Law students were conducted, as well as integrative and literature reviews. They are presented in Chart 1.

Chart 1 - Presentation of studies: title, results and conclusions selected in the study

\begin{tabular}{|c|c|c|c|}
\hline Author & Title & Some Results & Conclusions \\
\hline $\begin{array}{l}\text { Piccini et al } \\
2011^{(9)}\end{array}$ & $\begin{array}{l}\text { The Living Will under the } \\
\text { perspective of doctors, } \\
\text { lawyers and students. }\end{array}$ & $\begin{array}{l}\text { Only } 29.2 \% \text { of respondents had full knowledge } \\
\text { of the Living Will meaning; } 87.6 \% \text { would opt for } \\
\text { orthotanasia with a terminal patient. }\end{array}$ & $\begin{array}{l}\text { Most professionals adopts the Living Will as } \\
\text { a form of respect to the patient's will and, } \\
\text { therefore, the patient's autonomy. }\end{array}$ \\
\hline $\begin{array}{l}\text { Campos et } \\
\text { al } 2012^{(10)}\end{array}$ & $\begin{array}{l}\text { The Living Will: the perception } \\
\text { of cancer patients and their } \\
\text { companions. }\end{array}$ & $\begin{array}{l}\text { Most of the interviewees, both patients and } \\
\text { companions, are unaware of the terms "Living } \\
\text { Will". }\end{array}$ & $\begin{array}{l}\text { There is an interest among oncology patients } \\
\text { and their companions to elaborate the Living Will } \\
\text { and add it to national legislation. }\end{array}$ \\
\hline $\begin{array}{l}\text { Alves } \\
2013^{(11)}\end{array}$ & $\begin{array}{l}\text { Language, Advance } \\
\text { Healthcare Directives and } \\
\text { Living Will: a national and } \\
\text { international interface. }\end{array}$ & $\begin{array}{l}\text { In Brazil, there is already a trend towards the creation } \\
\text { of specific legislation to meet Advance Directives, } \\
\text { since } 1999 \text {. In the National Congress, Law No. } 6.715 \text {, } \\
\text { of } 2009, \text { provides for amending the Penal Code (PC) } \\
\text { to exclude the unlawfulness of orthatanasia. }\end{array}$ & $\begin{array}{l}\text { There is still much legal discussion regarding the } \\
\text { contextualization and legality about this topic. }\end{array}$ \\
\hline $\begin{array}{l}\text { Dadalto et } \\
\text { al } 2013^{(7)}\end{array}$ & $\begin{array}{l}\text { Advance Healthcare } \\
\text { Directives: a Brazilian model. }\end{array}$ & $\begin{array}{l}\text { It was noticed that the Brazilian model should be } \\
\text { distanced from the standards of forms used in } \\
\text { many US states and Spanish provinces, aiming to } \\
\text { leave room for the subjectivity of each patient. }\end{array}$ & $\begin{array}{l}\text { The proposal aims to assist patients and doctors } \\
\text { in the Advance Healthcare Directives and } \\
\text { should be used as a guide considering each real } \\
\text { situation. }\end{array}$ \\
\hline $\begin{array}{l}\text { Crippa et } \\
\text { al } 2013^{(12)}\end{array}$ & $\begin{array}{l}\text { Advance Healthcare } \\
\text { Directives and the civil } \\
\text { responsibility of doctors. }\end{array}$ & $\begin{array}{l}\text { The civil responsibility of medical doctors before } \\
\text { Resolution } 1.995 / 2012 \text {. Objective and subjective } \\
\text { civil responsibility. }\end{array}$ & $\begin{array}{l}\text { Today, there is still little discussion as to the } \\
\text { doctor's responsibility as for disobeying these } \\
\text { Advance Healthcare Directives. }\end{array}$ \\
\hline $\begin{array}{l}\text { Bussinguer } \\
\text { et al } 2013^{(13)}\end{array}$ & $\begin{array}{l}\text { The right to live one's } \\
\text { own death and its } \\
\text { constitutionality. }\end{array}$ & $\begin{array}{l}\text { Legislative omission and consideration of the } \\
\text { possible legal binding of doctors and relatives of } \\
\text { terminally ill patients to their Living Will. }\end{array}$ & $\begin{array}{l}\text { Doctors are subject to the early manifestation } \\
\text { of terminally ill patients and are supported } \\
\text { by the Constitution in cases in which they are } \\
\text { legally questioned about the legality of their } \\
\text { subordination to the patient's directives and to } \\
\text { the Resolution of the Federal Medical Council. }\end{array}$ \\
\hline $\begin{array}{l}\text { Nunes et al } \\
2014^{(14)}\end{array}$ & $\begin{array}{l}\text { Advance Healthcare } \\
\text { Directives: benefits, obstacles } \\
\text { and limits. }\end{array}$ & $\begin{array}{l}\text { The heart of AHD: autonomy; the questionable } \\
\text { stability of decisions; the ambiguous terminology } \\
\text { used in AHD; alternative approaches. }\end{array}$ & $\begin{array}{l}\text { The need for studies in Brazil that will enlighten and } \\
\text { clarify the various aspects of AHD, so that dignified } \\
\text { death is not only a concept but also a reality. }\end{array}$ \\
\hline $\begin{array}{l}\text { Pattela et } \\
\text { al 2014(15) }\end{array}$ & $\begin{array}{l}\text { Patient's Advance Directives: } \\
\text { a brief introduction to the } \\
\text { topic. }\end{array}$ & $\begin{array}{l}\text { Advance Directives in the Brazilian legal system; } \\
\text { approaches in clinical practice. }\end{array}$ & $\begin{array}{l}\text { The ethical-legal recognition of the Advance } \\
\text { Directives will have a double role: if, on the one } \\
\text { hand, it will provide the doctor with a legal } \\
\text { provision to comply with it, on the other, and } \\
\text { especially, will guarantee the patient to be treated } \\
\text { according to his/her own will in its terminality. }\end{array}$ \\
\hline
\end{tabular}


Chart 1

\begin{tabular}{|c|c|c|c|}
\hline Author & Title & Some Results & Conclusions \\
\hline $\begin{array}{l}\text { Kovács } \\
2014^{(16)}\end{array}$ & $\begin{array}{l}\text { On the way to death with } \\
\text { dignity in the } 21^{\text {st }} \text { century. }\end{array}$ & $\begin{array}{l}\text { Portraits of death in the twenty-first century: } \\
\text { interdict death, open death, rehumanized death, } \\
\text { patients with advanced diseases and their needs. } \\
\text { Euthanasia, dysthanasia, orthatanasia, assisted } \\
\text { suicide - bioethical issues. The Living Will, } \\
\text { Advance Healthcare Directives: documents for } \\
\text { orthothanasia. }\end{array}$ & $\begin{array}{l}\text { Death with dignity is the goal of palliative care } \\
\text { programs. It seeks to facilitate the patient's } \\
\text { autonomy in making decisions about his or her } \\
\text { life. The concept of good death, without pain, } \\
\text { is resumed with respect to the patients' will, } \\
\text { establishing channels of communication with } \\
\text { their family and health professionals. }\end{array}$ \\
\hline $\begin{array}{l}\text { Saldanha } \\
2014^{(17)}\end{array}$ & $\begin{array}{l}\text { The possible flaws of the } \\
\text { Living Will in Brazilian law } \\
\text { against the constitutional } \\
\text { guarantee of dignified death. }\end{array}$ & $\begin{array}{l}\text { Euthanasia and other procedures of the Advance } \\
\text { Healthcare Directives of comparative law } \\
\text { Resolution No. } 1.995 / 2012 \text { of the Federal Council } \\
\text { of Medicine of the juridical aspects, a principle of } \\
\text { human dignity. }\end{array}$ & $\begin{array}{l}\text { Active euthanasia (characterized by an action); } \\
\text { passive euthanasia (characterized by an } \\
\text { omission): Brazilian law does not allow for either } \\
\text { of these hypotheses, although the preliminary } \\
\text { draft of the Penal Code provides for the } \\
\text { possibility of passive euthanasia. }\end{array}$ \\
\hline $\begin{array}{l}\text { Salles } \\
2014^{(18)}\end{array}$ & $\begin{array}{l}\text { Bioethics and the processes } \\
\text { of religiosity among patients } \\
\text { with terminal diseases in } \\
\text { Brazil. }\end{array}$ & $\begin{array}{l}\text { Dilemmas of spiritual nature in the terminality } \\
\text { of life. The role of Bioethics in the religious } \\
\text { processes of terminality, applying the principles } \\
\text { of autonomy and otherness. }\end{array}$ & $\begin{array}{l}\text { The health professional must know the main } \\
\text { spiritual trends of the country to respect the } \\
\text { principles of beneficence and respect for the } \\
\text { autonomy of the patient. }\end{array}$ \\
\hline $\begin{array}{l}\text { Cogol et al } \\
2015^{(19)}\end{array}$ & $\begin{array}{l}\text { Advance Healthcare } \\
\text { Directives to terminal } \\
\text { patients: an integrative } \\
\text { review. }\end{array}$ & $\begin{array}{l}\text { Perceptions, opinions and behaviors of students } \\
\text { and professionals; receptiveness of patients and } \\
\text { their families to the directives. }\end{array}$ & $\begin{array}{l}\text { The repercussions of AHD on the world scenario } \\
\text { contributing to reflections in Brazil, guided by } \\
\text { the CFM Resolution and their legal aspects. }\end{array}$ \\
\hline $\begin{array}{l}\text { Cassol et al } \\
2015^{(20)}\end{array}$ & $\begin{array}{l}\text { Advance Healthcare } \\
\text { Directives: perception of a } \\
\text { Nursing team of hemato- } \\
\text { oncology. }\end{array}$ & $\begin{array}{l}\text { They pointed out that the Advance Directives } \\
\text { would be something new for professionals, } \\
\text { within the context of care. }\end{array}$ & $\begin{array}{l}\text { Significant repercussions have been observed, } \\
\text { ranging from disregarding its use to the } \\
\text { conclusion that doctors and family members } \\
\text { still have decision-making power over the fate of } \\
\text { terminal patients. }\end{array}$ \\
\hline $\begin{array}{l}\text { Silva et al } \\
2015^{(21)}\end{array}$ & $\begin{array}{l}\text { Knowledge of Medical } \\
\text { students about the Living Will. }\end{array}$ & $\begin{array}{l}\text { Few students were aware of the meaning of the } \\
\text { term "Living Will". After hearing the definition } \\
\text { of the Advance Healthcare Directives, provided } \\
\text { by the researchers, the majority stated that they } \\
\text { would respect the provisions of the Living Will. }\end{array}$ & $\begin{array}{l}\text { The need to intensify this discussion between } \\
\text { society and students of Medicine, given its high } \\
\text { relevance to future doctors and the autonomy of } \\
\text { patients. }\end{array}$ \\
\hline $\begin{array}{l}\text { Chehuen } \\
\text { Neto et al } \\
2015^{(22)}\end{array}$ & $\begin{array}{l}\text { Living Will: what do health } \\
\text { professionals think about it? }\end{array}$ & $\begin{array}{l}\text { Fewer than half of those interviewed said they } \\
\text { knew the document. Most of the sample was } \\
\text { uncomfortable to follow the determinations of a } \\
\text { Living Will. }\end{array}$ & $\begin{array}{l}\text { The majority of health professionals interviewed } \\
\text { are unaware of the Living Will and CFM } \\
\text { Resolution } 1.995 / 2012 \text {. }\end{array}$ \\
\hline $\begin{array}{l}\text { Cogo et al } \\
2016^{(23)}\end{array}$ & $\begin{array}{l}\text { Challenges to introduce } \\
\text { the Advance Healthcare } \\
\text { Directives into the hospital } \\
\text { practice. }\end{array}$ & $\begin{array}{l}\text { Fear of legal implications. Advance Healthcare } \\
\text { Directives require patient autonomy and } \\
\text { adequate communication. }\end{array}$ & $\begin{array}{l}\text { Conflicts, dilemmas and limitations in the } \\
\text { applicability of AHD make it impossible for the } \\
\text { patients' will to be respected. }\end{array}$ \\
\hline $\begin{array}{l}\text { Coco et al } \\
2017^{(24)}\end{array}$ & $\begin{array}{l}\text { Advance Directives: will of } \\
\text { health professionals and } \\
\text { family caregivers. }\end{array}$ & $\begin{array}{l}\text { Focus on the applicability of the Advance } \\
\text { Healthcare Directives and the will of professionals } \\
\text { and family in the maintenance of the dignity } \\
\text { and the personal autonomy; insecurity of the } \\
\text { applicability of the directives. }\end{array}$ & $\begin{array}{l}\text { Although participants accepted and wanted } \\
\text { to implement the Advance Directives, they } \\
\text { expressed concerns about their applicability, } \\
\text { whether their will were not respected, or that } \\
\text { they could change as they faced the final stage } \\
\text { situation, their abandonment by professionals } \\
\text { and their insecurity regarding diagnoses and } \\
\text { prognoses. }\end{array}$ \\
\hline $\begin{array}{l}\text { Moreira et } \\
\text { al } 2017^{(25)}\end{array}$ & $\begin{array}{l}\text { The Living Will in medical } \\
\text { practice: professionals' } \\
\text { comprehension. }\end{array}$ & $\begin{array}{l}\text { Advance Healthcare Directives are important to } \\
\text { promote patient autonomy; humanization of } \\
\text { medical care in terminality. }\end{array}$ & $\begin{array}{l}\text { It also demonstrates the need to create a legal } \\
\text { device regulating its formal use in Brazil. }\end{array}$ \\
\hline $\begin{array}{l}\text { Buriá et al } \\
2017^{(26)}\end{array}$ & $\begin{array}{l}\text { The application of Advance } \\
\text { Healthcare Directives in } \\
\text { people with dementia. }\end{array}$ & $\begin{array}{l}\text { This instrument, if used with healthy elderly } \\
\text { people, anticipates the possible installation } \\
\text { of posterior cognitive damage, indicated by } \\
\text { demographic and epidemiological data. }\end{array}$ & $\begin{array}{l}\text { It is concluded that qualified professionals can } \\
\text { guide elderly people and their families to reflect } \\
\text { deeply on health and illness, autonomy and } \\
\text { inability. }\end{array}$ \\
\hline $\begin{array}{l}\text { Oliveira et } \\
\text { al } 2014^{(27)}\end{array}$ & $\begin{array}{l}\text { Euthanasia under the } \\
\text { perspective of undergraduate } \\
\text { Nursing students: conception } \\
\text { and challenges. }\end{array}$ & Ignorance as for the Living Will. & $\begin{array}{l}\text { The Constitution and laws prevent the } \\
\text { application of the Living Will. }\end{array}$ \\
\hline $\begin{array}{l}\text { Nunes } \\
2009^{(28)}\end{array}$ & $\begin{array}{l}\text { Proposal on the suspension } \\
\text { and abstention of treatment } \\
\text { in terminally ill patients. }\end{array}$ & Listed proposals. & $\begin{array}{l}\text { The use of orthotanasia as a medical practice } \\
\text { depends on the wide discussion among } \\
\text { professionals and the society. }\end{array}$ \\
\hline
\end{tabular}




\begin{tabular}{|c|l|l|l|}
\hline Author & \multicolumn{1}{|c|}{ Title } & \multicolumn{1}{c|}{ Some Results } & \multicolumn{1}{c|}{ Conclusions } \\
\hline $\begin{array}{c}\text { Pan } \\
\text { Chacon et } \\
\text { al } 1.995^{(29)}\end{array}$ & $\begin{array}{l}\text { The "noble lie" for the person } \\
\text { with cancer. }\end{array}$ & $\begin{array}{l}\text { Only 22\% of those surveyed stated that they } \\
\text { provided complete information to the patients under } \\
\text { their care. Of the practitioners who adopted the } \\
\text { "noble lie" in their clinical practice, approximately } \\
90 \% \text { said they would like to receive complete } \\
\text { information if they were in the patients'shoes. }\end{array}$ & $\begin{array}{l}\text { As ethical consequences triggered are the } \\
\text { stimulus to the paternalistic and protective } \\
\text { attitudes towards patients and the consequent } \\
\text { interference in the full exercise of their } \\
\text { autonomy. }\end{array}$ \\
\hline
\end{tabular}

\section{DISCUSSION}

Death can be seen through different prisms since ancient times. Dying close to the family, encouraging the continuity of will and sharing goods were valued in the Middle Ages ${ }^{(16)}$. In this way, unexpected and solitary deaths were not the predominant desire. The view of death presented a different view than that of contemporary times.

Nowadays, prolonging and isolating the lives of many patients leads to the growing desire for a quick and painless death, with relatives present, dying with dignity and preserving patients' beliefs and values ${ }^{(30)}$.

When the subject "dying with dignity" is approached, there is intense discussion. Palliative care programs focus on death with dignity, facilitating the patient's autonomy in decisions that involve prolonging life. Thus, good death, painless, respecting the will of patients, establishes a new topic of communication between family members and health professionals ${ }^{(16)}$.

Bioethics seeks to show a new direction to the impasse between religiosity and AHD, emphasizing autonomy, beneficence and otherness. When technology and death are confronted, there are relevant and complex ethical dilemmas. Many questions arise, leading people to reflect and question their human values. The complexity increases when the spiritual element is added to these reflections, effervescing ethical and existential questions about the interventions of the health professional. In this sense, when it comes to AHD, it is necessary to establish exact criteria for good clinical practice, because when the principle of alterity is approached health professionals can have their perception modified when putting them in the patient's shoes ${ }^{(31)}$.

The option of persisting in the treatment of terminally ill patients, instead of opening dialogue about possibilities of endof-life procedures, may lead to difficulties and changes in the comfort zone of health professionals. It is not possible to deny the limitations on the implementation of AHD, either by the feeling of impotence or by the therapeutic obstinacy of professionals ${ }^{(23)}$. On the other hand, for family caregivers, hiding the diagnosis from the terminal patient impairs adherence to the practice of AHD.

An alternative is the approach of terms called Advanced Care Planning, which expresses the preference or refusal of the patient to certain interventions, such as mechanical ventilation, parenteral nutrition and hemodialysis as care goals ${ }^{(32)}$.

Since AHD are an instrument of patients and involve decisions of the medical professionals and the proxy, it is fundamental that the difference between the model of pure autonomy and the substitute judgment be clarified. Whereas the former applies exclusively to patients who were already autonomous and expressed an autonomous or preferably relevant decision, the latter seeks to unveil what the patient's will would be if he/ she could express his/her will, a situation in which the proxies act as if they were the patient. Given these definitions, the AHD containing patient guidelines and the appointment of a proxy include both models ${ }^{(33)}$.

There are three clinical states in which decision-making on the end-of-life are cited in AHD interviews: terminal illness, persistent vegetative state, and advanced dementias. However, there is still a conflict between cultural and individual values and technical criteria. On the other hand, the medical professional fears fulfilling the patient's desire and suffering the consequences of judicialization of Medicine. It is justified that both the CFM and the Legislative Branch should be directed and defined to provide legal support for health professionals to reformulate their concepts regarding AHD, since the refusal of patients to be hydrated and fed by probes becomes invalid if the professionals do not respect their desire ${ }^{(7)}$.

As can be seen, in the midst of conflicts and discussions already mentioned, the patient's AHD are located, an instrument written in advance to be applied at the end of the author's life, a moment that generates so many ethical, legal and religious controversies.

The LW is helpful here, and can be understood as the act of caring for the patient, allowing him or her to join or dispense with treatments and/or procedures at the end of life, and ensuring control in decisions about his/her health. The Living Will appeared in the United States in the late 1960s as a written statement refusing perceived treatments, such as therapeutic obstinacy, which should be given to doctors, family members, and legal representatives ${ }^{(7)}$. In this context, therapeutic obstinacy is also discussed as well as palliative care observed in complex cases that new technologies and scientific knowledge offer ${ }^{(34)}$. During these discussions, terminal patients and the goal of alleviating and reducing suffering must not be forgotten. The LW humanizes care and reduces suffering.

A recent study conducted in Rio Grande do Sul State shows that the nursing team has little knowledge about AHD. It is a recent and important topic and should be addressed and discussed both in the academy and in professional practice. Thus, the extensive discussion on the topic will lead to the valorization of the patient's guidelines and will, and legal aspects in Brazil(20).

AHD are recent themes in the patient care scenario, which aim to attend to and respect the autonomy of patients or their family members. However, they also produce discussions and conflicts among health professionals because they modify the routines used in patient care ${ }^{(20)}$.

The Federal Constitution of 1988 guarantees rights to citizens, and among them is the principle of human dignity, which can be understood as a subjective and personal satisfaction. Thus, granting the death-conscious request to a terminal patient would not be contrary to Article 5 of the Federal Constitution. Nevertheless, 
some authors do not understand it in this way, since men take all the risks and suffer all the consequences of living with a dynamic society and becoming increasingly freer from prejudice ${ }^{(16)}$.

Avoiding death is related to new medical technologies, which fascinates people and health professionals. Death has been replaced from houses to hospitals. Currently, death in an unexpected and violent manner has increased, and occurs, to a large extent, without protection or care. Under a different perspective, with the approach of death, terminal patients and their families can have access to humanized death, accepting suffering, focusing attention on the patient, returning to the natural process of dying, with respect, humility, without banishment or banalization ${ }^{(16)}$.

Terminal patients are stigmatized and labeled, and there is an expectation of pain, suffering, and isolation at death. In addition, the patient experiences a feeling of powerlessness, distancing from the family, work, causing loss of autonomy and health ${ }^{(16)}$.

Medical technology is present in diagnostics and treatments, allowing significant progress in curing diseases and extending life. However, it is necessary to consider possible damage of prolonging the life of sick people. What is behind this discussion is the need to put people at the center of the process, favoring dignity and autonomy of their choices, the sense of belonging - provisions that become even more urgent when it comes to vulnerable people. Humanization involves solidarity, compassion, rapprochement and respect ${ }^{(16)}$.

At first, technology assists in improving methods to ensure longer life for a terminally ill patient, since some methods are not enough to achieve cure and sometimes only prolong the patient's suffering ${ }^{(1)}$.

With the advancement of medical technology, the prolongation of life and the conflicts generated about the theme, the change in the connotation of euthanasia is questioned. Despite legal support, religious, scientific, and ethical issues continue in conflict with patients, family members, representatives, and health professionals. The main purpose of euthanasia is leading to death to abbreviate pain; that of dysthanasia is preventing death at any cost. Orthotanasia seeks death with dignity at the right moment, controling pain and physical and psychic symptoms, as well as issues related to social and spiritual dimensions ${ }^{(16)}$.

Euthanasia means the medical procedures aimed at shortening patient's life, such as the application of a lethal medication or the withdrawal of a fundamental device for the patient, e.g., artificial ventilation. On the other hand, dysthanasia is considered the reverse procedure of euthanasia, in which the doctor uses extreme means, such as devices and innovations in the area, to maximize the patient's life ${ }^{(35)}$.

Euthanasia can be classified in an active and passive way, so that passive euthanasia is more commonly accepted, since it aims to end the patient's suffering and pain; however, it is not characterized as a medical action, but as a suspension of a medical therapy applied to the terminal patient. Therefore, the health professional stops practicing an action or a procedure that could prolong life, usually by interrupting the treatment ${ }^{(36)}$. Dysthanasia means etymologically the "exaggerated prolongation of the agony, suffering and death of a patient", that is, it is the medical procedure that follows the opposite direction of euthanasia, since it aims to prolong the patient's life until the last moment. Orthotanasia is a way of guaranteeing the dignity of the patient, without disrespecting his/her will, and it has a conformity between his/her will and the fundamental principle, guaranteed constitutionally. In the etymological sense, some authors observe the antagonism of euthanasia and dysthanasia, but refer to a similarity with morality and ethics in its application ${ }^{(36)}$.

To carry out the Living Will, it suffices to have civil capacity and registration, and it will be valid until its revocation or the death of the author. The public deed, or proxy, does not express the real will, because the disease process does not exist; under this process, the will may be contrary to that previously expressed in the will written.

The proxy will be able to assist the medical staff when the family is against the will written and to decide when the LW is omitted, since the doctor feels it is difficult to respect the AHD when the family is contrary to this will ${ }^{(7)}$.

Legally, the doctor is not bound to Resolution CFM 1.995/2012, in an ethical manner related to the LW, not being obliged to abide by them, because there is freedom guaranteed by the Federal Constitution, which in its article 5, paragraph II, reports that nobody will be obliged to do or not to do anything, except if provided in law. There is no legal prohibition, and the doctor can, legally, not abide by the patient's AHD ${ }^{(13)}$.

The patient's and the health professional's insecurity to use and accept AHD faces the fear of violating ethical and legal norms of Resolution 1.995/2012, which has no force of law. The absence of legal force makes an important instrument for interpreting and directing legal hermeneutics possible, and the fact that AHD are not prescribed by law does not immediately exclude their inclusion in the legal system of the country ${ }^{(15)}$.

The future applicability of Resolution 1.995/2012 involves important elements such as bioethical and legal aspects, language and the end of life. However, the Brazilian context does not have any law that makes it possible to legislate on the elaboration of a document that expresses the patient's will.

The discussion about the so-called orthotanasia is on the agenda in Bill No. 6.715 of 2009, of the Federal Senate, which foresees to amend the Penal Code (CP) to exclude from unlawfulness orthotanasia, that is, the "discontinuation of disproportionate and extraordinary therapeutic measures for the artificial maintenance of patients' lives in imminent and inevitable death attested by two doctors"(8).

The civil responsibility of doctors is very much related to the role that these professionals have been developing, i.e., the responsibility to save lives using several means of treatment. What are the limits to take responsibility for the failure of treatment or for errors and what are the limits that can follow; and to what extent will he be held liable for non-compliance ${ }^{(12)}$ ?

The great question of AHD regards what kind of civil liability will be applied: the objective, which is independent of guilt and which configures damage and the causal link of guilt; or subjective, which is related to guilt in which the causative agent will be held liable if he/she has acted guiltily or wilfully. As noted, there is still no jurisprudence and doctrines on the subject, since they are relatively recent directives ${ }^{(12)}$.

The civil liability of doctors is, as a rule, subjective and can be held liable if they do not respect these AHD and, consequently, do 
not respect patients' autonomy. It should be noted that, although there is no specific law regarding the Advance Healthcare Directives, the Code of Medical Ethics and Resolution CFM 1.995/2012, which deal with the issue, are broad rules to be followed and respected ${ }^{(12)}$.

The subject is quite controversial and is still being discussed in several countries, so that in some countries there are already resolutions or even laws that allow the LW. In Italy and Portugal there is no express regulation that it, nor even the appointment of a proxy ${ }^{(37)}$.

The right to life also refers to the moment of death. The Federal Constitution in its Article 5 caput determines the inviolability of the right to life as an unwaivable right ${ }^{(38)}$, that is, something you cannot decide, make it what you want, refers to its own right to use.

At the moment life ends, the principle of the dignity of a person appears, which means that every person has the right to a dignified death. As expected, the draft of the new Penal Code typifies active Euthanasia with imprisonment. Passive euthanasia is characterized by an omission or the expression of the will of both the family and the patient in not being subjected to life by artificial means ${ }^{(39)}$.

Fears related to legal implications appear as a determining and limiting factor in the application of AHD by nurses, doctors and family caregivers in the hospital context. CFM Resolution $1.995 / 12$ still raises questions as to its applicability ${ }^{(23)}$. Moreover, an uncertainty of the patient's diagnosis added to the ignorance of his/her illness and prognosis are points that translate into fears of professionals and family members ${ }^{(24)}$. The multiprofessional team recognizes patients' autonomy rights at the terminal stage. However, when it is necessary to dialogue with relatives so that they can express themselves on the patient's will, there is no security to attend to the exposed will, due to the understanding that relatives are in a moment of suffering.

Resolution CFM 1.995/12 states that it is up to doctors to record AHD in the medical record when they are communicated directly by the patient. The patient's expression of will interferes greatly with medical conduct and, in most cases, the licensed authority is technically vulnerable to do so $^{(7)}$.

A legal responsible for making decisions when the patient is terminally ill is a way of maintaining and accepting the patient's will. However, relatives prefer that decisions be coordinated between the medical staff and the patient ${ }^{(10)}$. With AHD, patients expose and discuss with their medical staff their will about which treatments they prefer to perform if they are terminally ill(40).

In Brazil, the level of knowledge among health professionals and students, regarding AHD, is a subject that is not well discussed in classes, since there are few studies on the subject. Despite this, the participants were prone to the acceptance of $\operatorname{AHD}^{(7,9,41)}$.

Surveys carried out in Spain and Australia found that more than $50 \%$ of lawyers, doctors and students were aware of the Living Will and declared themselves in favor of its implementation, provided that it is regulated, since the patient's will are to be respected.

A study found that the professionals interviewed still have difficulty dealing with this issue and that they would feel more capable of fulfilling the desire expressed by the terminal patient if the law to support clinical practice was established ${ }^{(13)}$. Other studies have found that students of Medicine have little knowledge about AHD. It was verified that the subject is discussed superficially in the discipline of Medical Ethics and, in view of this result, there is a need to insert the subject in discussions and clarifications of the theme throughout medical training ${ }^{(43-44)}$. On the other hand, terminal cancer patients, after orientations, prefer to edit their own LW, and the companions agree with this point of view ${ }^{(20)}$.

Deciding about what to do or not to the terminally ill patient is always an ethical dilemma for doctors ${ }^{(45)}$. AHD allow doctors and their health care team to respect the patient's autonomy and fulfill their will in the face of numerous palliative treatment options. However, asking the patient or his/her representative to decide what kind of treatment should be done or not is a broad ethical dilemma ${ }^{(46)}$.

The doctor-patient relationship based on respect and ethics is fundamental for the family to consider accepting the will expressed by the patient or designated by his/her legal representative when there is no more possibility for cure, thus respecting patients' autonomy ${ }^{(15)}$.

\section{Study limitations}

As a limitation, the small number of studies found in the literature is pointed out; for future investigations it is recommended to expand the databases.

\section{Contributions to the Nursing, Health or Public Policy fields}

The present study synthesized the main results regarding AHD, generating a broad vision and providing knowledge and visualization of the most varied lines of debates, encouraging new studies to be conducted on ethical, technical and managerial impacts in the clinical practice of Nursing. As member of the multiprofessional team, Nursing based on care, regardless of expectation of healing, feels the impact of the challenge of being before someone who has already decided not to be kept alive. The care plan is being transformed as it reorients the care route once linked to comfort, enhancing existing skills such as better patient care.

\section{FINAL CONSIDERATIONS}

With the present study, it is concluded that the number of papers on Advance Healthcare Directives in Brazil is still not expressive. The AHD present themselves as a concept that is still not widely spread and is not very clear, in its essence, in the studies found. The studies present several approaches: the position and performance of the health professional, health technologies, the family and their legal representatives, the patient, the social, cultural and religious contexts, the forms of communication and their ambiguities, legislation and resolutions. Notwithstanding, it all appears in a fragmented way. Through this, this study summarized the approaches and the focus of each debate, thus generating a broad vision about Advance Healthcare Directives and enabling its application in an adequate, coherent and global way with the patient. 


\section{REFERENCES}

1. Pessini L. [At the origins of bioethics: Potter's bioethical creed to Fritz Jahr's imperative bioethical]. Rev Bioét [Internet]. 2013 [cited 2017 Oct 13];21(1):9-19. Available from: http://dx.doi.org/10.1590/S1983-80422013000100002 Portuguese.

2. Pinto LF, Baia AF. A representação da morte: desde o medo dos povos primitivos ateus a negação na atualidade. Rev Humanae [Internet]. 2013 [cited 2017 Oct 13];7(1). Available from: http://humanae.esuda.com.br/index.php/humanae/article/view/74/66

3. Martin LM. Eutanásia e distanásia. In: Costa SI, Oselka G, Garrafa V (coords.). Iniciação à Bioética [Internet]. Brasília: Conselho Federal de Medicina 1998 [cited 2017 Oct 14]. p. 171-92.. Available from: https://portal.cfm.org.br/images/stories/biblioteca/iniciao\%20\%20biotica.pdf

4. Assembléia Legislativa do Estado de São Paulo. Lei 10.241, 17 de março de 1999. Os direitos dos usuários dos serviços e das ações de saúde no Estado e dá outras providencias. Governo do Estado de São Paulo [Internet]. São Paulo: Secretaria da Assembléia Legislativa do Estado de São Paulo; 2001 [cited 2017 Oct 14]. [about 2 screens]. Available from: https://www.al.sp.gov.br/repositorio/legislacao/lei/1999/ lei-10241-17.03.1999.html

5. Conselho Nacional dos Direitos da Criança e do Adolescente (CONANDA). Resolução No 41 de 17 de outubro de 1995. Os direitos da criança e do adolescente hospitalizada [Internet]. Diário Oficial da União: República Federativa do Brasil; 1995 [cited 2018 Nov 3]. Oct 17, Seção 1: [about 1 screen]. Available from http://www.mpdft.mp.br/portal/pdf/unidades/promotorias/pdij/Legislacao\%20e\%20 Jurisprudencia/Res_41_95_Conanda.pdf

6. Conselho Federal de Medicina (CFM). Resolução n. 1995, 9 de agosto de 2012. Dispõe sobre as diretivas antecipadas de vontade dos pacientes [Internet]. Diário Oficial da União: República Federativa do Brasil; 2012 [cited 2018 Nov 3]. Aug 31Seção 1: [about 5 screens]. Available from: http://www.portalmedico.org.br/resolucoes/cfm/2012/1995_2012.pdf

7. Dadalto L, Tupinambás U, Greco DB. [Advanced directive: a brasilian model]. Rev Bioét [Internet]. 2013 [cited 2017 Oct 20];21(3):463-76. Available from: http://dx.doi.org/10.1590/S1983-80422013000300011 Portuguese.

8. Mendes KDS, Silveira RCCP, Galvao CM. [Integrative literature review: a research method to incorporate evidence in health care and nursing]. Rev Text Contexto Enferm [Internet]. 2008 [cited 2017 Oct 23];17:758-64. Available from: http://dx.doi.org/10.1590/S010407072008000400018 Portuguese.

9. Piccini CF, Steffani JA, Bonamigo EL, et al. [Living will in the perspective of doctors, lawyers and students]. Rev Bioethikos [Internet]. 2011 [cited 2017 Oct 24];5(4):384-91. Available from: https://saocamilo-sp.br/assets/artigo/bioethikos/89/A4.pdf Portuguese.

10. Campos MO, Bonamigo EL, Steffani JA, et al. [Living wills: perception of oncology patients and accompanying family members]. Rev Bioethikos [Internet]. 2012 [cited 2017 Oct 24];6(3):253-9. Available from: https://saocamilo-sp.br/assets/artigo/bioethikos/96/1.pdf Portuguese.

11. Alves CA. [Language, Advance Directives and Living Will: a national and international interface]. Rev Bioethikos [Internet]. 2013 [cited 2017 Oct 24];7(3):259-70. Available from: https://saocamilo-sp.br/assets/artigo/bioethikos/105/1810.pdf Portuguese

12. Crippa A, Buonicore GP, Feijó AGS. [Advance directives of will and the civil responsibility of the Physician]. Rev AMRIGS [Internet]. 2013 [cited 2017 Oct 24];57(4):344-8. Available from: http://www.amrigs.org.br/revista/57-04/0000222859-15_1288_Revista\%20AMRIGS.pdf Portuguese

13. Bussinguer ECA, Barcellos IA. [The right to live one's own death and its constitutionality]. Rev Ciênc Saúde Colet [Internet]. 2013 [cited 2017 Oct 24];18(9):2691-8. Available from: http://dx.doi.org/10.1590/S1413-81232013000900024 Portuguese

14. Nunes MI, Anjos MF. [The advance directive: benefits, obstacles and limits]. Rev Bioét [Internet]. 2014 [cited 2017 Oct 24];22(2):241-51. Available from: http://dx.doi.org/10.1590/1983-80422014222005 Portuguese.

15. Pattela LHD, Alves RGO, Loch JA. [Advanced directives by the patient: a brief introduction to the theme]. Rev AMRIGS [Internet]. 2014 [cited 2017 Oct 24];58(2):162-5. Available from: http://www.amrigs.org.br/revista/58-02/014.pdf Portuguese

16. Kovács MJ. [Towards death with dignity in the XXI Century]. Rev Bioét [Internet]. 2014 [cited 2017 Oct 24];22(1):94-104. Available from: http://dx.doi.org/10.1590/S1983-80422014000100011 Portuguese.

17. Saldanha RR. [The possible failures of the vital will in the brazilian right in front of the constitutional guarantee of the worthy death]. Rev Bioet Latino Am [Internet]. 2014 [cited 2017 Oct 24];14(1):143-68. Available from: http://www.saber.ula.ve/handle/123456789/39041 Portuguese.

18. Salles AA. [Bioethics and religious processes among terminally ill patients in Brazil]. Rev Bioét [Internet]. 2014 [cited 2017 Oct 24];22(3):397406. Available from: http://dx.doi.org/10.1590/1983-80422014223021 Portuguese.

19. Cogo SB, Lunardi VL. [Anticipated directives will to the terminal patients: integrative review]. Rev Bras Enferm [Internet]. 2015 [cited 2017 Oct 24];68(3):524-34. Available from: http://dx.doi.org/10.1590/0034-7167.2015680321i Portuguese.

20. Cassol PB, Quintana AM, Velho MTAC. [Anticipated policy will: perception of nursing staff of blood-oncology]. Rev J Nurs Health [Internet]. 2015 [cited 2017 Oct 24];5(1):04-13. Available from: doi: http://dx.doi.org/10.15210/jonah.v5i1.5497 Portuguese.

21. Silva JAC, Souza LEA, Costa JLF, et al. Knowledge of medical students regarding living wills. Rev Bioét [Internet]. 2015 [cited 2017 Oct 24];23(3):563-71. Available from: http://dx.doi.org/10.1590/1983-80422015233093 
22. Chehuen Neto JA, Ferreira RE, Silva NCS, et al. Living will: What do healthcare professionals think about it?. Rev Bioét [Internet]. 2015 [cited 2017 Oct 24];23(3):572-82. Available from: http://dx.doi.org/10.1590/1983-80422015233094

23. Cogo SB, Lunardi VL, Quintana AM, et al. Challenges to implementation of advance directives of will in hospital practice. Rev Bras Enferm [Internet]. 2016 [cited 2017 Oct 30];69(6):969-76. Available from: http://www.scielo.br/pdf/reben/v69n6/0034-7167-reben-69-06-1031.pdf

24. Cogo SB, Lunardi VL, Quintana AM, et al. Advance directives: wills of health professional and Family caregivers. Rev Baiana Enferm [Internet]. 2017 [cited 2017 Oct 30];31(1):e16932. Available from: doi 10.18471/rbe.v31i1.16932

25. Moreira MADM, Costa SFG, Cunha MLDM, et al. Physician's perceptions for including living will in medical practice. Rev Bioét [Internet]. 2017 [cited 2017 Nov 18];25(1):168-78. Available from: http://dx.doi.org/10.1590/1983-80422017251178

26. Burlá C. A aplicação das diretivas antecipadas de vontade na pessoa com demência [Thesis on the Internet]. Porto: Programa Doutoral em Bioética, Faculdade de Medicina da Universidade do Porto - FMUP/Portugal, Conselho Federal de Medicina -CFM/Brasil. 2015 [cited 2017 Nov 26]. 159 p. Available from: https://repositorio-aberto.up.pt/bitstream/10216/82654/2/114101.pdf

27. Oliveira MLC, Cavalcanti EO, Alves VP, et al. Euthanasia from the perspective of nursing undergraduate students: concepts and challenges. Rev Min Enferm [Internet]. 2014 [cited 2017 Dec 18];18(1):134-141. Available from: doi: http://www.dx.doi.org/10.5935/1415-2762.20140010

28. Nunes R. Proposta sobre suspensão e abstenção de tratamento em doentes terminais. Rev Bioética [Internet]. 2009 [cited 2018 Jan 18];17(1):29-39. Available from: http://revistabioetica.cfm.org.br/index.php/revista_bioetica/article/view/77

29. Pan Chacon J, Kobata C, Liberman S. A mentira piedosa para o canceroso. Rev Assoc Med Bras. 1995;41(4):274-6.

30. Menezes RA. Em busca da boa morte: antropologia dos cuidados paliativos. Rio de Janeiro: Garamond; 2004.228 p.

31. Asai A FS, Lo B. Attitude of Japanese and Japanese-American physicians towards life sustaining treatment. Lancet [Internet]. 1995 [cited 2018 Jan 21];346(8971):356-9. Available from: doi:https://doi.org/10.5555/uri:pii:S014067369592230X

32. Stone J. Advance directives, autonomy and unintended death. Rev Bioethics [Internet]. 1994 [cited 2018 Jan 23];8(3):223-46. Available from: https://doi.org/10.1111/j.1467-8519.1994.tb00256.x

33. Beauchamp TL. Princípios de ética biomédica. 3 ed. Rio de Janeiro: Loyola. 2002. 576 p.

34. Nebot C, Ortega B, Mira J, et al. Dying with dignity. A study of living wills. Gac Sanit. 2010;24(6):437-45. doi:10.1016/j.gaceta.2010.09.006

35. Pithan LH. A dignidade humana como fundamento jurídico das "ordens de não-ressuscitação». 1 ed. Porto Alegre: EDIPUCRS. 2004.137 p.

36. Bento LA. Bioética: Desafios éticos no debate contemporâneo. 1 ed. São Paulo: Paulinas, 2008. 462 p.

37. Kfouri Neto MI. Testamento Vital. Rev Judic Paraná [Internet]. 2006 [cited 2018 Jan 18];1:201-16. Available from: http://www.revistajudiciaria. com.br/portfolio-posts/revista-judiciaria-do-parana-edicao-02-2/

38. Parizotto T. Polêmica: Eutanásia à luz do Direito. Rev Jornal da UEM [Internet]. J Univ Est Maringá [Internet]. 2011 [cited 2018 Jan 28];101:[about 2 screens]. Available from: http://www.jornal.uem.br/2011/index.php/ edicoes-2011/87-jornal-101-setembro-2011/759-eutanasia-a-luz-do-direito

39. Carvalho GM. Aspectos Jurídicos-penais da Eutanásia. São Paulo: IBCCRIM; 2001. 206 p.

40. Holland S. Bioética enfoque filosófico. São Paulo: Loyola. 2008. 304 p.

41. Stolz C, Gehlen G, Bonamigo EL, et al. Manifestation of patient's anticipated will as dysthanasia inhibiting factor. Rev Bioét [Internet]. 2014 [cited 2018 Jan 28];19(3):833-45. Available from: http://revistabioetica.cfm.org.br/index.php/revista_bioetica/article/view/679

42. Sánchez AV, Villalba SF, Romero PMG, Barragán SG, Rufino Delgado MT, Garcia MTM. Documento de voluntades anticipadas: opinión de los profesionales sanitarios de Atención Primaria. Rev Semergen [Internet]. 2009 [cited 2018 Jan 29];35(3):109-162. Available from: doi:10.1016/ S1138-3593(09)70717-8

43. Gusmão A. [Living will]. Arq CRMPR [Internet]. 2013 [cited 2018 Jan 20];30(118):1-2. Available from: http://crmpr.org.br/publicacoes/ cientificas/index.php/arquivos/article/view/437

44. Bomtempo TV. A ortotanásia e o direito de morrer com dignidade: uma análise constitucional. Rev Int Direito Cid [Internet]. 2011 [cited 2018 Jan 22];(9):169-182. Available from: http://www.ipebj.com.br/docdown/_7ce.pdf

45. Schiff R SP, Snook J, Rajkumar C, Bulpitt CJ. Living wills and the mental capacity act: a postal questionnaire survey of UK geriatricians. Age Ageing [Internet]. 2006 [cited 2018 Jan 11];35(2):116-21. Available from: https://doi.org/10.1093/ageing/afj035

46. Martínez K. The living will. An Sis Sanit Navarra [Internet]. 2007 [cited 2018 Jan 26];30(Suppl 3):87-102. Available from: http://scielo.isciii.es/ pdf/asisna/v30s3/original6.pdf 